\title{
ADULT EDUCATION AND NATIONAL TRANSFORMATION IN NIGERIA
}

\author{
MUHAMMAD, MUSA USMAN
}

Department of Educational Foundations, Sokoto State University, Sokoto, Nigeria

\begin{abstract}
This is a discussion on Adult Education programmes and National Transformation in Nigeria. The study was necessitated by observing the various efforts made by the Nigerian government, local and international interventions from 1980s to date and the present literacy rate and the present level of development in Nigeria. Adult education connotes a desirable change that can improve the role of adult population in their community and national development. It is not the children, but the adults who hold in their hands the destiny of a society. The paper reviewed the various transformational plans implemented in Nigeria from 1980s to date. It also reviewed how the Chinese and American governments implemented and used adult education programmes to bring developmental changes in their countries. It concluded that, being a means of acquiring general knowledge, skills, values, social and political changes by adults, the Nigerian government did not give adult education due priority and that was why most of the government programmes and plans failed in the past.. Some of the recommendations include: to adequately finance adult education programmes and give sustainable and effective priority to achieve the desired objectives.
\end{abstract}

\section{Introduction}

Johnson (1990) stated that adult education is not only a means of learning skills of writing and reading but a vital and positive contribution to human liberation and development. It is a tool for creating consciousness that would allow the neo-literate to understand the inherent social and other problems in his society and start thinking of actions and means to transform the identified problems. Basically, identification of a problem or problems is a pre-requisite to development or transformation. Ideally, no one can identify everyone's problems. In this respect, everyone must be literate so as to be able to identify their problems by themselves and think of actions to solve those problems; this is a basic means of transformation. As Omolewa (2001) in Awolowo (1951) cited,

To educate the children and enlighten the illiterate adults is to lay a solid foundation not only for future social and economic progress but also for political stability. A truly educated citizen is in my view as the only means of transforming Nigeria........

Education in general remains the key to human development. It is seen as the driving force for meaningful developments in every human society. The goal of any educational system is to provide or develop a balanced individual capable of surviving in his environment and contributing meaningfully towards the survival of that society to which he belongs. Adult education is one of the principal professions that can take adequate care of socio-economic, cultural, political and environmental problems of the adults. The success of adult education in terms of achieving its goals as stated in the National Policy on Education (2004) cannot be over-emphasized. An adult education program changes the social and psychological minds of adults more than any other profession, installs lost hope in them and liberate them from their prejudice of seeing themselves as not being capable of learning. Adult education awakens 
adult learners to become aware of their environmental (social, economic, cultural and political), psychological potentials and hidden abilities. It also exerts enormous influence on the larger society in terms of National Transformation (Onyenemezu, 2012). Adult education is concerned not only with preparing people for life, but helping people (adults) to live more successfully as useful and acceptable members of their societies and contribute meaningfully to the transformation of those societies (Fasokun, 2006).

When Nigeria is compared with other countries that became independent during the same period with it, it is to be seen that life expectancy in Nigeria is 46.94 years while in Switzerland it is 80.95 years and in Malaysia it is 74 years respectively. Similarly, over $70 \%$ of Nigeria's citizens live below poverty line of $\$ 1.5$ per day. As a result Nigeria is ranked $156^{\text {th }}$ out of 187 countries in the world ranking of nations using the human development index (Youth Link, 2013 in UNDP, 2011). In Switzerland, 7.4\% of the population is below the poverty line. The Multidimensional Poverty Index (MPI) shows that $54.1 \%$ of the population live in poverty, with 57.3\% in intense deprivation (Youth Link, 2013 in UNDP, 2011).

Transparency International in its 2014 Corruption Perception Index ranked Nigeria 136th out of 174 countries, 144th in 2013, 139th in 2012 and 143rd in 2011 out of 183 countries in the world (Transparency International 2014). Internationally, Nigeria is perceived as a corrupt heaven up to date. From the above picture, if transformation is a choice for other countries, then it is a necessity for Nigeria (Youth Link, 2013).

\section{Adult Education}

The definition of adult education at this point has become necessary to make this discussion meaningful and identify the basic issues examined in this paper. Adult education was defined from different perspectives. Most writers seem to agree that adult education is the education geared towards the adult. This gives rise to the question "who is an adult".

An adult as a concept, just like adult education has been defined by various authors and writers using different parameters. Some use the biological parameters in defining it, while others use the chronological, historical, economic, psychological, political and social parameters in defining who is an adult.

Ibeh (2008) sees an adult as a person who has achieved full physical development and is expected to have right to participate as a responsible homemaker, worker and member of society. Nzenere (2010) perceives an adult as a person who is physically and psychologically mature, and an individual who is socially, economically, politically, culturally and environmentally responsible. Looking at the above definitions of an adult, two key words recur, which are maturity and responsibility. Ibeh (2008) also maintained that in advanced countries, an adult is one who has attained the voting age of twenty one (21) years and more, while in developing countries like Nigeria, such a person has to attain the voting age of 18 years. Adulthood depends on the criteria prescribed by society in order to identify an adult in that society. 
Adult education has various definitions from different authorities and writers. However, UNESCO (1976) in Nzeneri (2010:10) defines adult education as:

The entire body of organized educational process, whatever the content, level and method, formal or otherwise, whether they prolong or replace initial education in schools, colleges and universities as well as apprenticeship, whereby persons regarded as adults by their society develop their abilities, enrich their knowledge, improve their technical and professional qualifications and bring about changes in their attitudes or behaviours in the two fold perspectives of full personal development (Nzeneri, 2010: 10).

United Nations Education, Scientific and Cultural Organization (UNESCO) (1997) maintained that, adult education is a tool that has the potential to meet people's most vital needs and to stimulate social, cultural, political and economic development, especially on the part of the disadvantaged groups of people. Similarly, United Nations Development Programmes asserted that, adult education is a means of acquiring knowledge at high or middle age whereas possessing knowledge is just like having access to resources for a decent standard of living and participating in community development programmes, therefore recognized adult education as a mechanism for the pursuit of human right. From the above definitions and explanations on adult education, it can be summarized that, it is an overall means of transforming the less privileged illiterates to meet up with the minimum standard required from every citizen so that the desired aims of the transformation agenda would be achieved.

\section{Transformation}

Transformation is a process of profound and radical change that orients an organization in a new direction and takes it to an entirely different level of effectiveness. The concept is unlike 'turn-around' which implies a basic change of character and has little or no resemblance with the past configuration or structure (Business Directory, 2013). National transformation implies fundamental change in the building blocks of a nation; change in the social, economic, infrastructural and political landscape of a nation. To determine the standard of a nation, it must be done in a comparative analysis. Where do we stand in relation to our peers? (Youth Link, 2013).

\section{Adult Education and National Transformation in Nigeria}

Transformation is a process of economic, social, political and cultural change engineered in a given society by the effort of all stakeholders, both internal and external, including the local communities, government, private sector, civil society organizations, NGOs, technical and financial development partners with the view to improving the conditions of life of the population in a sustainable way (Fasokun, 2006). 
The role of adult education in development is multidimensional. Indeed, as one of the building blocks of human development and not just a basic right, education, including adult education, is a foundation for progress in areas such as human capital, health, nutrition and the development of institutions and democracy. Therefore, the role of adult education in development can be understood through the complex relationships existing between all its forms and the economic, political, social and cultural determinant factors of African development. The economic role of adult education in development is apparent in its contribution to human capital formation. It is now well established that, alongside health care, sanitation, and nutrition that improve people's standards of living and productivity by reducing sickness and mortality rates and by increasing life expectancy, adult basic education, by equipping recipients with essential literacy and numeracy skills, yields high rates on investment, thereby enhancing labour and productivity. An educated population also provides a more attractive investment climate. Thus, investment in the development of human capital, through adult education is crucial for developing a labour force and managerial know-how able to compete in today's global economy. Formal education alone is not sufficient for playing this role as even those categories of the population who have had formal education and training might need to be updated and re-skilled through adult education, mainly because today's knowledge society tends to render previously acquired knowledge and skills inappropriate and obsolete. Adult education is also instrumental in familiarizing the active population of Africa with Information Communication Technology (ICT), a decisive tool for the smooth integration of African economies in the global economy. The importance of this cannot be overemphasized as the world is rapidly moving towards knowledge-based economic structures and information societies that comprise networks of individuals, firms and countries linked electronically in interdependent and interactive relationships (Fasokun, 2006).

Adult education also plays a major role in social development. It is now widely admitted that economic growth will not reduce poverty unless poor people are able to actively participate in it. Such participation can become effective to a large-extent through adult education. Indeed, the African population will need some kind of formal and non-formal education and training to be able to benefit from basic health care, including sexual and reproductive health services, the development of new medicines, and thus be in a position to free itself from diseases that devastate poor people, such as HIV/AIDS, tuberculosis, Ebola virus, malaria and other parasites. Adult education will also be needed to enable the African poor to really take advantage of programs aimed at protecting orphans and vulnerable children or drastically reducing the number of people without access to safe water and basic sanitation in the framework of the African water vision and the G8 Water Action plan. Adult education geared towards women is another powerful means to contribute to socio-economic development. As the Report of the Commission for Africa pointed out (Fasokun, 2006).

In the words of a one time Director General of UNESCO as reported in Omolewa (2001: 1);

It is not the children of today who hold the present destiny of Africa in their hands, it is the adults. So, it is only by establishing effective communication with the adult population, by helping them to adjust 
to a rapidly changing world, that an immediate impact can be made on urgent problems of society and essential progress to be brought about.

This view is very true because it is the adult who occupies the production sectors of our economy not children who by their education are for the future. Adult education has been employed solving different situational problems in different societies of the world. Omolewa (2001:2) is in agreement with this situation when he also maintained that:

Strongest and desirable role Adult education can and does play is in redressing injustice, deprivations and oppression suffered victims of pseudoequalitarianism and insincerity of purpose in the provision made for the general good in education training and functional learning.

With the world becoming a global village, adult education helps to breakdown stereotype ideas and reduces prejudices, injustice, deprivation and oppression. By implication, this means that adult education in addition to being a tool for global peace and harmony makes the educated adults to be more sophisticated and polished in their chosen profession. Farley (2010) observes that: "People who are more educated know why they are not supposed to make prejudice comments and consequently disguise their prejudices." Adult education should be geared towards solving the problems of injustice, deprivation and oppression which will in turn bring peace and harmony among adult members of the country. It will solve these current problems of kidnapping, youth restiveness and indiscriminate bombing in the country (Farley, 2010).

Nigeria is not strange to transformation agenda or plan. Before 1980s, reforms were purely in form of extended national perspectives. Plans that attempted to mobilize human, material and natural resources of the nation to achieve goals of national life were put in place. There were the 1962 - 1968 plan, 1970 - 1974 plan, 1975 - 1980 plan, 1981 - 1985 plan, Green Revolution, War Against Indiscipline, etc. Often these plans went beyond mere economic prescriptions to address social, human and political goals. Thus, $1970-1974$ plan defined the National objectives to be the building of:

i. A united, strong and self-reliant nation

ii. Great and dynamic economy

iii. Just and egalitarian society

iv. Land of bright and full opportunities for all citizens

v. Free and democratic society (Shehu, 2006).

In 1980s, the need for reform paved the way for stabilization/austerity measures of the Shagari administration. Although in 1982, Shagari launched the National Mass Literacy Campaign which was well articulated and planned to meet the nation's objectives in order to stabilize the country socially, educationally and more specially politically. But unfortunately, the programme ended up assisted by United Nations Development Program (UNDP) and 
other foreign donors because of the inability or failure of government to run the mass literacy programme effectively (Omolewa, 2001).

In 1986, came the structural adjustment programmes introduced by Babangida administration to address the fundamental and structural imbalance in the economy, strengthen the currency and build a viable, sustainable, industrial infrastructure upon which real economic growth and development could be found. The president did not know the literacy level of his country and planned on adjusting a country with a literacy rate of less than 50\% (Osisiama, 2010).

Abacha's administration introduced vision 2010 which aimed to develop a blue print that wouldl transform the country and place it firmly on the route to become a developed nation by the year 2010. The general objectives of vision 2010 was to transform the country into a united industrious, caring and God-fearing democratic society committed to make the basic needs of life affordable for everyone and create Africa's leading economy. He further projected that by 2010, Nigerians would have discovered themselves and revert to being God-fearing, caring, sincere, honest, accountable in their dealings with public trust and proud of their country and heritage. How could this be possible without a literacy rate in a country of at least $90 \%$, whereas the literacy rate was less than $50 \%$ by then?" (Osisioma, 2010).

In 2004, Obasanjo administration introduced the National Empowerment and Development Strategy (NEEDS). The NEEDS reform program rested on four key strategies, viz:

i. Reforming government and institutions

ii. Growing the private sector

iii. Implementing a social character and value re-orientation

Obasanjo administration ignored adult education or did little on it. He launched Universal Primary Education (UPE) in 1976 and Universal Basic Education (UBE) in 1999 (upon that, the aim was not achieved because there was a gap) (Osisioma, 2010).

In 2007, Yar Adua administration articulated the 7-Point Agenda for National Development. The 7-point revolved around Energy, Education, Agriculture, Infrastructure, Wealth creation and Poverty alleviation, Land reform and security. These reforms would catapult Nigeria to the rank of one of the 20 most developed countries by the year 2020. All these without any plan for adult education in a country with $52 \%$ literacy rate (Abdullahi, 2006).

In 2011, Goodluck Jonathan promised to radically transform the nation and overhaul every aspect of the national life. His agenda also defined its goals in these words: The policies and programs directed at addressing governance will focus on the public service, security, law and order, legislature, anti-corruption measures and institutions, judiciary, economic coordination and support for private sector investment. These will be addressed through the implementation of the recommendations in the above sectors reform. The senior politician did not learn anything from his predecessors' mistakes (Asobia, 2012). 


\section{Adult Education and Transformation Index in the United States of America (U.S.A)}

Manning (2003) conducted a research on the positive outcomes achieved by literacy programmes of the USA. He stated that, adult literacy programmes are increasingly being called upon in the US to prove that they are very effective programs because learners who attended literacy and adult education programs made progress as participants as well as their families, employers and communities has benefited. The report explained how adult education programmes helped to produce positive outcomes in aspects of life such as: employment and earning, welfare and poverty, health, correction of prison inmates, children, women and employment. The research found that the following skills were acquired by participants: $85 \%$ of participants acquired greater willingness and ability to learn for life, $84 \%$ has improved ability to listen, understand, learn and apply information, $84 \%$ acquired more positive attitude toward change, $80 \%$ acquired better ability to build and work in team, $73 \%$ improved their capacity to think critically and act logically to evaluate situations, solve problems and make decisions, 87\% improved their moral and self esteem (Manning, 2003).

\section{Adult Education and Transformation in China}

China has the largest most populated and most diversified adult education system in the world. No matter the literacy program, literacy education, adult higher education, cultural learning have all been enjoying emphasis from the Chinese government, social organizations and citizens (Chinese Adult Education Association, 2008). As an important component of modern education in China, adult education is a kind of basic education for continuously developing adult's talent and other potentials, improving adults moral and scientific competences and helping them adopt themselves to the economic, cultural, political and social changes.

Meanwhile, the Chinese Government considers adult education as a broad channel for satisfying people's diversified needs in life and helping them realize individual development and personality perfection (Chinese Adult Education Association, 2008). The Chinese adult education association was imposed by the government to carry out the following tasks:

i. Provide post training for those employed for enabling them to meet the requirements in morality, knowledge, professional skills and practical capacity.

ii. To provide basic education to those employed labourers who have not completed primary and secondary education.

iii. To provide relevant professional, and cultural education to those employed who have completed secondary and higher education but cannot meet requirement for their posts.

Adult education has been recognized as a necessity to enhance development especially in an era of globalization, not only because it produces human capital, but also because it enable people to become well-informed citizens capable of thinking critically and owning their destiny through active participation. Upon all the roles played by adult education to transform a nation (very low budgetary allocations were devoted to adult education programmes in Nigeria) indicating low priority given to adult education. considering the 
transformational roles played by adult education programmes worldwide and the unsuccessful transformations that took place in Nigeria by the past administrations, as a result of less concern given to adult education whereas close to half of the citizens are illiterates. Now time has come for adult education to be granted top priority by the government at all the three levels, similarly foreign efforts are also required to strengthen the system of adult education in Nigeria.

\section{Challenges Confronting Adult Education in Nigeria}

From colonial era to date, adult education programmes were run mostly through voluntary efforts in Nigeria. The challenges confronting adult education in Nigeria are summarized as follows:

i. Compared with other forms of education in Nigeria is adult education is neglected by the government. There are insufficient learning centres in the townships and those in the villages have no access to adult education. The curriculum does not suit the interest of most of the learners.

ii. Most of the administrators of adult education in Nigeria are not professionals of the field. Similarly, must of the instructors are senior school graduates or dropouts.

iii. Insufficient funding of adult education programmes and corruption which lead the programmes to sharing or lack of infrastructure and learning materials.

iv. Inadequate consideration for adult education programme graduates while recruiting staff in both governmental and non-governmental organizations.

\section{Conclusion}

It was concluded in this paper that adult education, referred to a transformation process of acquiring general knowledge as well as skills, values, attitudes, change of behaviours and vocations meant for mature people, it is a powerful tool for transformation including poverty reduction and attainment of the MDGs. Yet this has not historically received the attention that it deserves in the Nigerian so called transformations from 1970s to date. This was found to be the reason why most of the government programmes and plans used to fail because the masses that are the focus point of the national development happen to be without the basic education and social character that they can use to help government achieve its objectives. These are the reasons why the numerous transformation plans in Nigeria failed.

\section{Suggestions}

The following were suggested for a successful implementation of National transformation using adult education as a tool: these are as follows:

i. There should be sustainable and effective priority should on adult education programmes in Nigeria by developing, expanding and creating more adult education centres in every village and in most areas in the towns to make it accessible to villagers and those in the townships. Similarly, to review the present 
curriculum to suit the interest of government learners and present technological development.

ii. The stakeholders should Employ professionals and dedicated administrators and facilitators and retain the current staff to revitalize adult education programmes to meet internatinal standard.

iii. Adult education Programmes should be funded sufficiently by the government itself not to rely on donors to meet the standard of adult education programmes in the developed nations.

iv. Graduates of adult education programmes should be given first consideration while recruiting junior staff in both government and non-governmental organizations. So that, learners will be motivated and everyone will be eager to enroll into the programmes.

These are the channels operated by the Chinese Government through adult education to become the fastest growing economy in the world today. Similarly China has remarkedly achieved outcomes in popularizing compulsory education, decreasing its illiteracy rate and satisfied young and aged people's needs for life and technical education (Chinese Adult Education Association, 2008).

\section{References}

Abdullahi, A. (2012). Challenges of Governance Need for Transformational Leadership. Paper presented at National Conference of ANAN, Abuja, October 9.

Asobie, A. (2012). "Challenges of Governance Need for Transformational Leadership" paper presented at National Conference of ANAN, Abuja, October 9. Retrieved on 16/11/2014 from www.managementnigeria.org/index.php.

Business Dictionary (2013). Retrieved on 16th August 2013 from www.businessdictionary.defini.

Chinese Adult Education Association (2008). National Report on Adult and Learning in China: Development and present Situations. Chinese National Adult Education Commission. Retrieved on 11/06/2011 from www.unesco.org/../chind.pdf

Farley, J.E. (2010). Majority - Minority Relations (6 ${ }^{\text {th }}$ ed.). New York: Prentice Hall.

Fasokun, E. (2006). Nigeria National Commission for Adult Education and the Challenges of Professionalizing Adult Education Delivery in Nigeria, in Adult and Non-Formal Education in Nigeria: Emerging Issues. Annual Conference, Calabar, Nigeria, Nov. 27 Dec. 1.

Ibeh, A.E. (2008). Theory and Practice of Adult Education in Nigeria. Journal of Education and Practice, 3(5):1-2. 
Johnson, (1990) in Dukku M.G. (1998). Historical Development of Adult Education in Sokoto State 1940 - 1976. Ph.D. Thesis, Usmanu Danfodiyo University, Sokoto, Nigeria.

Manning, A. (2003). Review of Research on Positive Outcomes Achieved by Literacy Programmes Making a Difference. Retrieved on 13/05/2010, from http://www.proliteracy.org.

Nzenerie, I.S. (2010). Adults in Battle: Any Hope of Victory? Journal of Education and Practice, 3 (5):2.

Omolewa, M.A. (2001). Adult Literacy Policy and Practice in Nigeria. In UNDP (2011) In Awolowo (1951). Adult Literacy Policy and Practice in Nigeria. In: Patel, H.A. (ed.), Learning Opportunities for All, ASPABE/ICAE, 2:52.

Onyenemezu, E.C. (2012). Adult Education and the Challenges of the $21^{\text {st }}$ Century in Nigeria. Journal of Education and Practice, 3:1-3.

Osisioma, B.C. (2010). "Electoral Reform and Good Governance: Path to a New Development." Paper presented at Inauguration of Governor of Anambra State, Awka, March 16, 2011. Retrieved on 15/08/2013 from www.nigeria70.com/../

Shehu, A.Y. (2006). Corruption, Rule of Law and Sustainable Development. Nigerian Journal of Economic and Financial, 1: April - June. Retrieved on 15/08/2013 from www.http://www.work.depress.com/prof.ben.osisioma/2/.

Transparency International, (2014).Corruption Perception Index.Retrieved on 6/9/2015 From https://www.transparency.org/cpi2014/....

United Nations Development Programme (2000). Performance and Future Challenges, Common Country Assessment of the United Nations Agencies in Uganda Retrieved on 09/01/2010 from http://www.iizdvv.de/index.php?article_id=400\&change1.

United Nations Education, Scientific and Cultural Organization (1997). Education for All, Global Monitoring Report Presented at Persepolis. Retrieved on 09/07/2010 from http://www.books.google.cabooks?hl=en\&/r=\&id=raidw.

Youth Link (2013). National Transformation. Paper Presented at National Youth Economic Summit, Abuja, November 30th. Retrieved on 18/11/2014 from www.statehouse.gov.ng/doc/trans 